Original Research

\title{
Increased the Intensity of Elderly Visit to Posyandu with Family Support
}

\author{
Desi Sandra Fatmawati1 ${ }^{1}$ Edy Soesanto² \\ ${ }^{1}$ Indonesian National Nurses Association of Central Java, Indonesia \\ ${ }^{2}$ University of Muhammadiyah Semarang, Indonesia
}

\section{Article Info}

Article History:
Accepted December 28th,
2019

Keywords:

Elderly; Family Support;

Intentional visits

\section{INTRODUCTION}

As a person ages, the physiological function will decrease due to the aging process thereby increasing the risk of many noncommunicable diseases appearing in the elderly. In addition, the degenerative process will reduce the body's resistance to infectious diseases. Degenerative diseases commonly suffered by the elderly are hypertension (57.6), arthritis (51.9), stroke (46.1), COPD (8.6) and DM (4.8). ${ }^{1}$

\section{Abstract}

The decline in health, especially in the elderly will affect the independence and quality of life of the elderly. The role of the family is needed to motivate the elderly in health checks to health services. One of the health services for the elderly is the elderly Posyandu which is an integrated health service for the community-based elderly. Based on data the level of elderly visits to Posyandu the elderly shows that the level of elderly visits to the Posyandu of the elderly is relatively low. The low number of elderly visits to Posyandu is influenced by several factors, one of them is the support from the family. The low number of elderly visits to Posyandu is influenced by several factors, one of them is the support from the family. The purpose of the research was to found out the relationship between family support and the intensity of elderly visits to PosyanduSumber Sehat. This research used a quantitative descriptive correlational study with a cross-sectional design. The sample in this study was 82 elderly respondents with a purposive sampling technique. The results showed that good family support was $46(56,1 \%)$ and less family support was $36(43,9 \%)$. The intensity of elderly visits in the low category was $48(58.5 \%)$ and there were $34(41.5 \%)$ with high visit intensity. There was a significant relationship between family support and the intensity of elderly visits to posyandu.
One of the government's efforts to improve the welfare and health status of the elderly is by organizing elderly Posyandu activities. This health service program approach is focused on integrated services by prioritizing promotive and preventive efforts on elderly health through empowerment and the active role of the community. The health service program is expected to be able to detect early on the health problems experienced by the elderly. ${ }^{2}$

Corresponding author:

Edy Soesanto

soesantoedisoes@gmail.com

South East Asia Nursing Research, Vol 1 No 3, December 2019

ISSN:2685-032X

DOI: https://doi.org/10.26714/seanr.1.3.2019.137-141 
The elderly Posyandu that is still actively held today is one form of health services for the elderly, one of which is the Posyandu Elder "Sumber Sehat" located at Rw 05 Kangkung Village. The list of the attendance rates of the elderly in the health source posyandu for the period January 2018 December 2018, shows that the coverage rate of elderly visits to the health source posyandu is only $14.2 \%$. This proves that the attendance rate is still very far from the expected coverage rate of $80 \%$ set by the Ministry of Health of the Republic of Indonesia. ${ }^{1}$

The low rate of absence of the elderly to the Posyandu for the elderly is influenced by several factors including the age of the elderly, the knowledge of the elderly about the benefits of the Posyandu, employment, the elderly attitude towards the use of the Posyandu, infrastructure, geographical location (distance of the elderly home to the location of the elderly Posyandu), the role of health workers and family support. ${ }^{3}$

Family support is very important in motivating the elderly to check their health conditions for health services because of the good physical and emotional family relationships. The existence of a family becomes something that is very needed by the elderly where the family can accompany and accompany the elderly to visit the Posyandu for the elderly. 4

Family support includes informative support in the form of advice, direction, and explanation. Instrumental support is the provision of tangible or physical assistance which can be in the form of goods, services, and supporting infrastructure advice including providing time opportunities. Emotional support in the form of giving attention, trust so that someone becomes convinced that other people are able to give love and affection to him and support assessment in the form of a positive assessment of the individual which includes feedback and approval. ${ }^{5}$
Based on the results of research conducted by another research that the highest level of support from families is good support at $88.1 \%$ and less support at $11.9 \%$. The majority of respondents received support from families, but in practice controlling their health respondents did not get full support from families, this indicated there were still $26.3 \%$ of families not taking time for respondents, and $24.9 \%$ did not want to take respondents to check into services health. ${ }^{6}$

The results of a preliminary study conducted by researchers on November 10 , 2018, by conducting interviews with 8 elderly people at the Posyandu elderly healthy sources, the results show that as many as 3 elderly people said that the factor that caused the elderly not to attend the posyandu was the healthy source because they forgot the posyandu schedule for the elderly and there were no family members who took the elderly to the elderly posyandu implementation site. Lack of support from families due to family members busy with their work so that families tend not to have much time to accompany and accompany the elderly.

\section{METHODS}

This type of research is a quantitative study that uses a descriptive correlational design with an approach carried out in a crosssectional way. In this study the population was the elderly who participated in the Posyandu elderly activities of Sumber Sehat in the last 3 months, amounting to 104 respondents. The sampling method used in this study is to use purposive sampling so that the sample becomes 82 respondents. This research was conducted at the Sumber Sehat elderly posyandu and in every elderly house registered following the elderly posyandu located in Rw 05 Kangkung Village. Data collection tool with a questionnaire sheet. The research process took place from 12 -25 July 2019. analyzed by univariate and bivariate (Spearman Rank Correlation test). 


\section{RESULTS}

Characteristics of respondents most of the respondents included in the category of elderly $76(92.7 \%)$, the majority of elderly women were $69(84.1 \%)$, education as many as 48 (58.5\%) respondents did not attend school, the elderly worked as farmers 44 (53.7\%), and 37 (45.1\%) respondents lived with children.

Based on table 1 above shows that of 82 respondents there are 46 elderly (56.1\%) get good family support while for the lack of support as many as 36 elderly (43.9\%). Based on table 1 above shows that of the 82 respondents there were 48 elderly (58.5\%) with low visit intensity. While 34 elderly (41.5\%) with high visits.

Table 1

Frequency Distribution of Elderly Characteristics in

\begin{tabular}{lcc}
\multicolumn{3}{c}{ Posyandu } \\
\hline Indicators & f & \% \\
\hline Elderly & 76 & 92,7 \\
Old Age & 6 & 7,3 \\
\hline Gender & 13 & 15,9 \\
Male & 69 & 84,1 \\
Famale & & \\
\hline Education & 48 & 58,5 \\
No school & 32 & 39 \\
Elementary school & 2 & 2,4 \\
Middle school & & \\
\hline Occupation & 31 & 37,8 \\
Does not work & 44 & 53,7 \\
Farmers & 7 & 8,5 \\
Entrepreneur & & \\
Status of Stay & 37 & 45,1 \\
Son & 24 & 29,3 \\
Couple & 20 & 24,4 \\
Spouse and Children & 1 & 1,2 \\
Sibling & & \\
\hline Family support level & 46 & 56,1 \\
Support & 36 & 43,9 \\
Less Supportive & & \\
\hline Intensity of Visit & & \\
Posyandu & 34 & 41,5 \\
Low & & \\
High & & \\
\hline
\end{tabular}

The results of the study revealed that the average visit intensity score was 5.9024 with a median value of 6 . The highest value was 11 and the lowest value was 1 and the standard deviation was at 2.20826. The data normality test results using KolmogorovSmirnov obtained a p-value of 0,000 so that the data obtained were not normally distributed, then the categorization is based on a median value of 6 .

The results of the study revealed that the mean family support score was 13.41 with a median value of 15 . The maximum value was 18 and the minimum value was 2 with the standard deviation being at 3.607. The results of normality test data using Kolmogorov-Smirnov obtained a p-value of 0,000 so that the data obtained were not normally distributed, then categorization is based on a median value of 15 .

Table 2

Description of Family Support for the Elderly in Posyandu

\begin{tabular}{lcc}
\hline \multicolumn{1}{c}{ Variable } & Mean & SD \\
\hline Family support & 13,41 & 3,607 \\
\hline Intensity of Visits & 5,9024 & 2,16373 \\
\hline
\end{tabular}

Table 3 shows that the majority of respondents who received active family support participated in posyandu for elderly with high intensity of visits as many as $28(34.1 \%)$ respondents, and a small portion of respondents who did not get support from families not actively participated in elderly Posyandu with low intensity of visits as much as 12 (14.6\%) respondents. The Spearman Rank Correlation test results obtained $\mathrm{p}$-value $=$ 0,000 meaning there is a significant relationship between family support and the intensity of elderly visits to the Sumber Sehat elderly posyandu in Rw 05 Kangkung Village.

Table 3

Relationship between Family Support and Intensity of Elderly Visit to Posyandu

\begin{tabular}{lccccc}
\hline \multirow{2}{*}{$\begin{array}{c}\text { Family } \\
\text { Support }\end{array}$} & \multicolumn{3}{c}{ Intensity of Visit } & \multirow{2}{*}{$\mathrm{p}$} \\
\cline { 2 - 5 } & $\mathrm{c}$ High & \multicolumn{3}{c}{ Low } & \\
\cline { 2 - 5 } Support & 28 & 34,1 & 18 & 22,0 & \\
Less support & 24 & 29,3 & 12 & 14,6 & 0,000 \\
\hline
\end{tabular}




\section{DISCUSSION}

The results showed that the majority of respondents received support from families as many as 46 respondents (56.1\%) while respondents who lacked family support were 36 respondents (43.9\%). The size of the support given by the family is closely related to the family's understanding of the perception of the benefits of health services for the elderly.

Support can be described as a feeling of belonging or belief that other people can play an active role in everyday life. Family support that is realized by giving attention, being sympathetic, and giving help and encouragement will lead to a feeling of being more stable and safe in the elderly. 7,8

Family support includes informative support in the form of giving information in solving a problem which includes giving advice, direction, and explanation, instrumental support is providing tangible assistance or fisk which can be in the form of goods, services and advice supporting infrastructure to help or help others including giving time opportunity. Emotional support in the form of giving attention, trust so that someone becomes convinced that other people are able to give love and affection to him as well as assessment support in the form of a positive assessment of individuals consisting of social support which includes feedback and approval. $^{5}$

The results showed that most of the elderly were not actively participating in the elderly posyandu with a low intensity of visits of 48 respondents (58.5\%). While the rest are 34 elderly (41.5\%) with high visit intensity. Factors that influence the intensity of elderly visits to posyandu elderly are gender. Based on the results of this study showed that the majority of the elderly who participated in the Posyandu for the elderly were women, amounting to 69 elderly (84.1\%). Most of the elderly who are male do not attend the posyandu for the elderly because they are still active at work, therefore they tend to not have much time to attend the posyandu for the elderly.

Another factor that influences the intensity of elderly visits to posyandu is work. In this study, it is known that some are still working as farmers, amounting to 44 elderly (53.7\%). Work is an activity that is carried out by someone continually to get compensation. This is caused because the elderly do not want to depend either financially or otherwise on the family. Most of the elderly want to live independently by not relying on family.

The Spearman Rank correlation test results obtained a p-value of $0,000(\mathrm{p}<0.05)$ so that it can be concluded that there is a significant relationship between family support and the intensity of elderly visits to the posyandu of healthy elderly sources. The correlation coefficient (r) of 0.586 , the value is in the range of a strong relationship level (0.51-0.75). These results are in line with another research which concludes that there is a relationship between family support and the level of depression in the elderly at the Posyandu Sejahtera GBI Setia Bakti Kediri. ${ }^{9}$

Family support is very instrumental in encouraging the interest of the elderly to participate in elderly Posyandu activities. The family can be the main support for the elderly if they always take the time to accompany or take the elderly to the posyandu, remind the elderly if they forget the posyandu schedule and try to help overcome all problems with the elderly. ${ }^{4}$

This is consistent with the theory Friedman which states that the family can function as the main support for its members so that members view that people who are supportive are always ready to provide help and assistance if needed. 


\section{CONCLUSION}

The most family support given to the elderly is a good support of 46 respondents (56.1\%). The intensity of elderly visits to posyandu for the elderly with healthy sources is mostly in the low category of 48 respondents (58.5\%). There is a relationship between family support with the intensity of elderly visits to Posyandu elderly.

\section{ACKNOWLEDGMENTS}

Thank you to all of the respondents and those who have helped this research.

\section{CONFLICTS OF INTEREST}

Neither of the authors has any conflicts of interest that would bias the findings presented here.

\section{REFERENCES}

1. Kemenkes RI. Infodatin Lanjut Usia (Lansia). Indonesia; 2016:12. doi:10.1016/S00404039(98)00661-3

2. Dinas Kesehatan Kota Semarang. Laporan Posbindu Di Kota Semarang Tahun 2013. 2014.
3. Sunaryo MK et al. Asuhan Keperawatan Gerontik.; 2015.

4. Sulistyorini, C., Pebriantri, S., Proverawati A. Posyandu Dan Desa Siaga. Yogyakarta: Nuha Medika; 2010.

5. Harnilawati. Konsep Dan Proses Keperawatan Keluarga. Pustaka As Salam; 2013.

6. Soesanto E, Istiarti T, Pietojo H. Praktik Lansia Hipertensi dalam Mengendalikan Kesehatan Diri di Wilayah Puskesmas Mranggen Demak. J Promosi Kesehat Indones. 2018;5(2):127-139. doi:10.14710/jpki.7.3.127-139

7. Friedman, M., Bowden, V., \& Jones E. Buku Ajar Keperawatan Keluarga; Riset, Teori dan Praktek. 2010.

8. Yanto A, Setyawati D. Dukungan Keluarga Pada Pasien Diabetes Mellitus Tipe 2 Di Kota Semarang. In: Seminar Nasional Universitas Muhammadiyah Semarang. Vol 1. Universitas Muhammadiyah Semarang: LPPM Universitas Muhammadiyah Semarang; 2017. http://eriset.unimus.ac.id/index.php/psn1201 2010/index.

9. Astuti VW. Hubungan Dukungan Keluarga Dengan Tingkat Depresi Pada Lansia Di Posyandu Sejahtera GBI Setia Bakti Kediri. J Penelit STIKES RS Baptis Kediri. 2010;3(2):7884. 